University of Nebraska - Lincoln

DigitalCommons@University of Nebraska - Lincoln

Agronomy \& Horticulture - Faculty Publications

Agronomy and Horticulture Department

1993

\title{
Genetic manipulation of tall fescue
}

Jeffrey F. Pedersen

University of Nebraska-Lincoln, jpedersen1@unl.edu

D. A. Sleper

University of Nebraska-Lincoln, sleperd@missouri.edu

Follow this and additional works at: https://digitalcommons.unl.edu/agronomyfacpub

Part of the Agricultural Science Commons, Agriculture Commons, Agronomy and Crop Sciences Commons, Botany Commons, Horticulture Commons, Other Plant Sciences Commons, and the Plant Biology Commons

Pedersen, Jeffrey F. and Sleper, D. A., "Genetic manipulation of tall fescue" (1993). Agronomy \& Horticulture -- Faculty Publications. 960.

https://digitalcommons.unl.edu/agronomyfacpub/960

This Article is brought to you for free and open access by the Agronomy and Horticulture Department at DigitalCommons@University of Nebraska - Lincoln. It has been accepted for inclusion in Agronomy \& Horticulture -Faculty Publications by an authorized administrator of DigitalCommons@University of Nebraska - Lincoln. 


\title{
Genetic manipulation of tall fescue
}

\author{
J.F. Pedersen ${ }^{a}$ and D.A. Sleper ${ }^{b}$ \\ 'USDA-ARS Wheat, Sorghum and Forage Unit, Agronomy Department, University of Nebraska, \\ Lincoln, NE 68583, USA \\ ${ }^{\mathrm{b}}$ Agronomy Deparment, University of Missouri, Columbia, MO 65211, USA
}

(Accepted)

\begin{abstract}
Pedersen, J.F. and Sleper, D.A., 1993. Genetic manipulation of tall fescue. Agric. Ecosystems Environ., 44: 187-193.

Genetic manipulation of tall fescue (Festuca arundinacea Schreb.) has not been altered by the discovery of the Acremonium coenophialum (Morgan-Jones and Gams)/grass interaction. However, tall fescue breeding programs have been affected greatly. The basic methods for genetically manipulating the grass have remained static. Tall fescue is an obligate out-crossing species, and most improvements are, therefore, captured in the form of an improved population developed through some form of mass or recurrent selection. What has changed is the breeder's ability to recognize genetic differences in the grass because of the confounding effect of $A$. coenophialum on plant phenotype. It is, therefore, critical that breeders recognize $A$. coenophialum status in their plants prior to selection. The other major change in tall fescue breeding since the discovery of the $A$. coenophialum/grass interaction is a tremendous increase in breeding activity.
\end{abstract}

\section{INTRODUCTION}

Methods of genetic manipulation of tall fescue have not been significantly altered by the discovery of the Acremonium coenophialum/grass interaction. However, tall fescue breeding programs have been greatly affected. In both forage and turf breeding programs, the presence or absence of $A$. coenophialum affects the value of the ultimate product. This knowledge has led to significant increases in market demand for new tall fescue cultivars and corresponding increases in breeding efforts to develop new cultivars.

Poehlman (1979) defines the basic elements of plant breeding strategy as: (1) recognizing the morphological traits and the physiological and pathological responses of plant species that are important for adaptation, yield, and quality of the crop species, (2) designing techniques that will evaluate the

Correspondence to: J.F. Pedersen, 329 Keim Hall, East Campus, University of Nebraska-Lincoln, Lincoln, NE 68583, USA. 
genetic potential for these traits in strains of the appropriate species, (3) searching out sources of genes for the desired traits that may be utilized in a breeding program, and (4) combining the genetic potential for these traits into an improved variety or cultivar. The above is a good description of plant breeding or genetic manipulation of tall fescue as well as of most other crops.

\section{ACREMONIUM AND THE RECOGNITION OF GENETIC POTENTIAL}

Poehlman's four elements could be condensed into: to recognize and combine the genetic potential for improved traits into an improved cultivar. Note the two verbs in the above sentence, recognize and combine. Both are important to the process of plant breeding. Recognizing genetic potential for improved traits is affected by the Acremonium/grass interaction. The presence or absence of $A$. coenophialum in tall fescue confounds our ability to recognize the genetic potential of tall fescue by altering its phenotype. This has been documented for many important traits, being discussed in depth by other authors at this symposium. The confounding effect of the Acremonium/grass interaction can be removed by eliminating all $A$. coenophialum infection from plants, or eliminating all $A$. coenophialum-infected plants from a breeding program, and is appropriate for most forage programs where development of $A$. coenophialum-free cultivars is the program objective. Conversely, programs utilizing the benefits of $A$. coenophialum infection should attempt to use uniformly infected plants to avoid the confounding effects of the Acremonium/grass interaction (Pedersen and Sleper, 1988).

The remainder of this paper will discuss genetic manipulation of tall fescue assuming absence of $A$. coenophialum infection. The discussion should also be directly applicable to programs utilizing uniformly infected plants, but readers should be cautioned that differential interactions between strains or biotypes of $A$. coenophialum and individual genotypes of tall fescue are possible. Additionally, much of the literature does not report $A$. coenophialum status and previously reported results may have been confounded by the effects of $A$. coenophialum infection of tall fescue prior to its discovery.

\section{FACTORS CONTROLLING GENETIC MANIPULATION}

The breeder's ability to recognize and combine genetic potential for improved traits into an improved cultivar is controlled by the reproductive habits of the plant and the variation available to the plant breeder for particular traits. Reproduction, cytogenetics, and taxonomy have been reviewed in depth in the American Society of Agronomy Monograph, Tall Fescue (Terrell, 1979; Berg et al., 1979), and more recently by Sleper (1985). Only those factors critical to breeding strategies will be discussed in this paper.

Tall fescue is perennial, highly self-sterile, exhibits severe inbreeding 
depression, and can be vegetatively propagated. It is an allopolyploid with cultivated forms being $2 n=6 x=42$ that are usually assumed (in practice) to exhibit normal disomic inheritance. Therefore, most tall fescue cultivars are actually random mating populations, and breeding strategies are based on population improvement schemes used in many other cross-pollinated crops.

\section{RECOGNIZING GENETIC POTENTIAL}

Falconer (1989) partitions differences we see, or phenotypic variance $\left(V_{\mathrm{P}}\right)$, into genetic variance $\left(V_{\mathrm{G}}\right)$ and environmental variance $\left(V_{\mathrm{E}}\right.$, with $V_{\mathrm{G}}$ being further partitioned into additive variance $\left(V_{\mathrm{A}}\right)$, dominance variance $\left(V_{\mathrm{D}}\right)$, and epistatic or interaction variance $\left(V_{\mathrm{I}}\right)$. The relationships between the above are: $V_{\mathrm{P}}=V_{\mathrm{G}}+V_{\mathrm{E}}=V_{\mathrm{A}}+V_{\mathrm{D}}+V_{\mathrm{I}}+V_{\mathrm{E}}$. The ability to recognize genetic potential could be viewed as the proportion of $V_{\mathrm{G}}$ to $V_{\mathrm{P}}$. This ratio, $V_{\mathrm{G}} / V_{\mathrm{P}}$ is the definition of heritability $\left(h^{2}\right)$ in the broad sense. Heritability in the narrow sense is defined as $h^{2}=V_{\mathrm{A}} / V_{\mathrm{P}}$ and is of most importance when determining breeding strategies because response to selection (defined below) is dependent on $V_{\mathrm{A}}$.

Estimates of $h^{2}$ for various traits in various tall fescue populations range considerably (Asay et al., 1974; Sleper et al., 1977; Buckner et al., 1981; Nguyen et al., 1982; Nguyen and Sleper, 1983a). However, for most traits the potential to make genetic gains exists. Even for traits such as in vitro dry matter disappearance, which have been reported as having insufficient variance to allow effective selection (Watson et al., 1978), genetic gains have been made (Sleper, 1985). Such discrepancies probably result from extrapolating experimental results from one population to another, or from the inadequacy of genetic models developed for diploid species when used to describe genetic variance in polyploids such as tall fescue (Nguyen and Sleper, 1983b).

When making selections, either phenotypic (individual plant) or genotypic (based on progeny) evaluation of individuals may be used. In theory, if $h^{2}$ is low, some type of genotypic evaluation (progeny testing) may be preferred to direct phenotypic selection because resemblance among parents and offspring is because of additive genetic effects. Stratified selection techniques can also be used to effectively reduce the impact of environmental variance. However, in practice, many tall fescue breeders rely on phenotypic selection because of the reduced time, and physical and financial inputs required to evaluate a single plant as compared with a plant's progeny.

\section{COMBINING GENETIC POTENTIAL}

After recognizing genetic potential in individual tall fescue plants, the breeder combines selected plants by mating them to produce an improved 
population. Subsequent generations are produced following random mating. As few as two individuals could be mated together, but considerably larger numbers are usually utilized. Improvements are 'captured' in the resulting random mating populations which are expected to reach genetic equilibrium according to the Hardy-Weinberg theory (Falconer, 1989).

Response to selection $(R)$ can be estimated from several factors. These included $V_{\mathrm{P}}, h^{2}$ (narrow sense), and the intensity of selection $(i)$ expressed in terms of the phenotypic standard deviation (Falconer, 1989). The response to selection is calculated as $R=i h^{2} \sqrt{ } V_{\mathrm{P}}$. Although $h^{2}$ and $V_{\mathrm{P}}$ are estimates of population parameters over which breeders have little or no control (other than choice of the population), $i$ is determined by the breeder. The intensity of selection within a population is normally influenced by the size of the population and the need to minimize inbreeding in subsequent generations. Populations of 1000 or more individuals are common in forage breeding programs, and selection intensities are frequently in the 10-20\% range.

\section{NON-TRADITIONAL APPROACHES}

Introgressing genes from other species including Italian ryegrass (Lolium multiflorum Lam.) $(2 \mathrm{n}=2 \mathrm{x}=14)$ and perennial ryegrass (Lolium perenne L. ) $(2 \mathrm{n}=2 \mathrm{x}=14)$ has been used in tall fescue improvement for over 30 years (Buckner et al., 1961). Producing these wide crosses is relatively simple. Ryegrass panicles are bagged prior to anthesis. When the first florets on the top of the panicle begin to shed pollen, a culm at a similar stage of maturity is removed from the tall fescue pollen parent, placed under the bag with the ryegrass panicle, and supported in a test tube of water until all pollen is shed. Such crosses typically produce several viable seeds with a low incidence of selfed seed (Pedersen and Burrus, 1989). The amphiploid progeny of such crosses are often sterile from cytological imbalance $(2 n=28)$. These can be made fertile by doubling the chromosome number $(2 n=56)$ via colchicine treatment, and introgressed into traditional breeding programs. If back-crossed with normal tall fescue, the chromosome number falls rapidly back to $2 n=42$ (Kleijer, 1987). However, a $2 \mathrm{n}=56$ amphiploid population derived from (Italian ryegrass $\times$ tall fescue $) \times($ Italian ryegras $\times$ tall fescue amphiploids $)$ and (giant fescue $\times$ tall fescue $) \times$ Italian ryegrass $\times$ tall fescue amphiploids ) crosses has been maintained for several generations in isolation (Pedersen et al., 1990).

New technologies including DNA transfer, selection at the cellular level, restriction fragment length polymorphisms (RFLPs), somaclonal variation, gamete-derived haploids, etc. also offer opportunities to enhance genetic manipulation of tall fescue. However, the use of these technologies in tall fescue lags behind major crop species. Haploid tall fescues have been produced via anther culture (Kasperbauer et al., 1980). Such haploid plants should allow direct selection for superior gametes, and may provide fertile homozygous 
parent lines for use in breeding programs. Tall fescue inflorescences have been cultured to produce callus and regenerate plants, presumably from somatic tissue (Eizenga and Dahleen, 1990), and somaclonal variation for meiotic irregularities has been demonstrated in regenerates from embryo-derived calli (Eizenga, 1989). Although purely conjecture at this time, it would appear that RFLP mapping of tall fescue and the ryegrasses would allow immediate and accurate tracking of ryegrass genetic material into the wide hybrids described above.

\section{ACTUAL BREEDING HISTORIES}

The above describes in theory how genetic potential in tall fescue is combined into improved cultivars. The remainder of this paper will describe how tall fescue cultivars have actually been developed. Four cultivars with diverse breeding backgrounds have been chosen to represent the divergence in breeding systems used in tall fescue improvement. The reader may note discrepancies between breeding theory and breeding practice, but should recognize that it is difficult to argue with success.

The cultivar 'Kentucky 31' is an ecotype discovered growing on a farm in Kentucky in 1931. Seed was simply collected and increased (Fergus and Buckner, 1972). Although this breeding technique is not elegant, 'Kentucky 31 ' probably represents the most successful or widely utilized cultivar of this species.

The tall fescue cultivar 'Adventure' is representative of cultivars developed by building elite populations followed by mass or recurrent selection. The base population for this cultivar was 17 plants selected from old turf areas. Following inter-mating (presumably), two cycles of recurrent selection were initiated. During each cycle, phenotypic selection for disease resistance was followed by progeny testing for turf performance under low soil fertility. At the end of the second cycle of selection, 145 clones were inter-mated to form the new population called 'Adventure' (Meyer et al., 1988).

The cultivar 'AU Triumph' is representative of cultivars developed by intensively screening one or more broadly based populations. Three thousand six hundred and thirty plants from 121 plant introduction accessions were screened for vigor, winter growth, regrowth, and disease resistance. One hundred and thirty-two plants were selected and clonally propagated four times for further selection. Twelve plants were ultimately identified as superior. Seed was collected from these 12 plants and bulked in equal quantities to yield over 1000 progeny. These progeny were then re-selected for early growth to form the new population called 'AU Triumph' (Pedersen et al., 1983).

The cultivar 'Kenhy' is representative of cultivars developed by a pedigree approach. Its development was initiated by producing fertile progeny from annual ryegrass $\times$ tall fescue hybrids. Selection was for vigor, soft lax leaves, 
and high moisture content during drought. Generations were advanced by selection among and within maternal families with no control of pollen. U1timately $112 \mathrm{n}=42$ plants were selected, and inter-mated to form 'Kenhy' (Buckner et al., 1977) (R.C. Buckner, personal communication, 1990).

\section{CONCLÚSIONS}

Prior to the discovery of the association of $A$. coenophialum with toxicosis in tall fescue in 1977 (Bacon et al., 1977), eight cultivars of tall fescue, 'Kentucky 31', 'Alta', 'Fawn', 'Kenwell', 'Kenmont', 'Goar', 'Missouri-96', and 'Asheville' had been released in the US (Asay et al., 1979). Since that time, genetic manipulation of tall fescue has remained largely the same with the added detail of recognizing $A$. coenophialum infection status of breeding populations and improved cultivars. However, 84 tall fescue varieties have been granted plant variety protection, or have been submitted for plant variety protection in the US (J. Barclay, personal communication, 1990) since 1977. This tremendous increase in tall fescue breeding activity is a reflection of the significance of the discovery of the advantages and disadvantages of $A$. coenophialum infection in tall fescue. The market demand for improved tall fescues has increased, and the grass industry has rapidly responded to the new demand.

\section{REFERENCES}

Asay, K.H., Nelson, C.J. and Horst, G.L., 1974. Genetic variability for net photosynthesis in tall fescue. Crop Sci., 14: 571-574.

Asay, K.H., Frakes, R.D. and Buckner, R.C., 1979. Breeding and cultivars. In: R.C. Buckner and L.P. Bush (Editors), Tall Fescue. Am. Soc. Agron., Madison, WI, pp. 111-139.

Bacon, C.W., Porter, J.K., Robbins, J.D. and Luttrell, E.S., 1977. Epichloe typhina from toxic tall fescue grasses. Appl. Environ. Microbiol., 34: 576-581.

Berg, C.C., Webster, G.T. and Jauhar, P.P., 1979. Cytogenetics and genetics. In: R.C. Buckner and L.P. Bush (Editors); Tall Fescue. Am. Soc. Agron., Madison, WI, pp. 93-110.

Buckner, R.C., Hill, H.D. and Burrus, II, P.B., 1961. Some characteristics of perennial and annual ryegrass $\times$ tall fescue hybrids and amphiploid progenies of annual ryegrass $\times$ tall fescue. Crop Sci., 1: 75-80.

Buckner, R.C., Burrus, II, P.B. and Bush, L.P., 1977. Registration of Kenhy tall fescue. Crop Sci., 17: 672-673.

Buckner, R.C., Burrus, II, P.B., Cornelius, P.L., Bush, L.P. and Leggett, J.E., 1981. Genetic variability and heritability of certain forage quality and mineral constituents in Lolium-Festuca hybrid derivatives. Crop Sci., 21: 419-423.

Eizenga, G.C., 1989. Meiotic analyses of tall fescue somaclones. Genome, 32: 374-379.

Eizenga, G.C. and Dahleen, L.S., 1990. Callus production, regeneration and evaluation of plants from cultured inflorescences of tall fescue (Festuca arundinacea Schreb.). Plant Cell, Tissue Organ Culture, 22: 7-15. 
Falconer, D.S., 1989. Introduction to Quantitative Genetics. Third Edition. Longman Scientific and Technical, Harlow, UK.

Fergus, E.N. and Buckner, R.C., 1972. Registration of Kentucky 31 tall fescue. Crop Sci., 12: 714.

Kasperbauer, M.J., Buckner, R.C. and Springer, W.D., 1980. Haploid plants by anther-panicle culture of tall fescue. Crop Sci., 20: 103-106.

Kleiger, G., 1987. Cytogenetic studies of crosses between Lolium multiflorum Lam. and Festuca aryndinacea Schreb. III. The generations $C_{1}, C_{2}$ and $C_{3}$. Plant Breeding, 99: 144-150.

Meyer, W.A., Rose-Fricker, C., Rose, B.L. and Berns, F., 1988. Registration of 'Adventure' tall fescue. Crop Sci, 28: 191.

Nguyen, H.T. and Sleper, D.A., 1983a. Genetic variability of seed yield and reproductive characters in tall fescue. Crop Sci., 23: 621-626.

Nguyen, H.T. and Sleper, D.A., 1983b. Theory and application of half-sib matings in forage grass breeding. Theor. Appl. Genet., 54: 176-196.

Nguyen, H.T., Sleper, D.A. and Matches, A.G., 1982. Inheritance of forage quality and its relationship to leaf tensile strength in tall fescue. Crop Sci., 22: 67-72.

Pedersen, J.F. and Burrus, Jr., P.B., 1989. Seed set in annual ryegrass $\times$ tall fescue crosses. Agron. Abstr., p. 94

Pedersen, J.F. and Sleper, D.A., 1988. Considerations in breeding endophyte-free tall fescue forage cultivars. J. Prod. Agric., 1: 127-132.

Pedersen, J.F., Haaland, R.L., Hoveland, C.S., Berry, C.D., Schmidt, S.P. and Harris, R.R., 1983. Registration of AU Triumph tall fescue. Crop Sci., 23: 182.

Pedersen, J.F., Eizenga, G.C. and Burrus, Jr., P.B., 1990. Registration of KY-2N56 tall fescue. Crop Sci, 30: 1163.

Poehlman, J.M., 1979. Breeding Field Crops, Second Edition. AVI Publishing Company, Westport, CT.

Sleper, D.A., 1985. Breeding tall fescue. In: Jules Janick (Editor), Plant Breed Reviews. Vol. 3. AVI Publishing, Westport, CT, pp. 313-342.

Sleper, D.A., Nelson, C.J. and Asay, K.H., 1977. Diallel and path coefficient analysis of tall fescue (Festuca arundinacea) regrowth under controlled conditions. Can. J. Genet. Cytol., 19: 557-564.

Terrell, E.E., 1979. Taxonomy, morphology, and phylogeny. In: R.C. Buckner and L.P. Bush (Editors), Tall Fescue. Am. Soc. Agron, Madison, WI, pp. 31-39.

Watson, Jr., C.E., Frakes, R.V., Chilcote, D.O., Sleper, D.A. and Matches; A.G., 1978. Genetic variation for perloline, $N$, and digestibility in tall fescue. Crop Sci., 18: 458-464. 